\title{
An investigation into the future of discretionary trusts in South Africa: An income tax perspective: Part 2
}

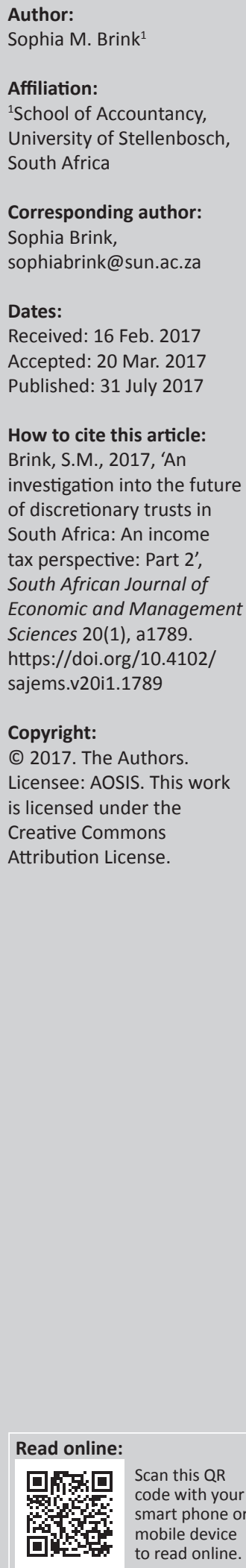

Background: Trusts have long been used as an estate planning mechanism, including the avoidance of estate duty and donations tax. In the 2016 National Budget the Minister of Finance indicated that Government was proposing several legislative measures during 2016/2017 to prevent individuals from using a trust to avoid estate duty (and donations tax to a certain extent). Unexpectedly, the 2016 draft Taxation Laws Amendment Bill and the final Amendment Bill did not give effect to any of these proposals, but introduced other less drastic measures to control the abuse of trusts for tax purposes, albeit with the same stated purpose.

Aim: The main aim of the study was to clarify the reform proposals (albeit unclear and consequently based on certain assumptions) and to compare the reform proposals with the final amendments. This comparison will shed some light on the fairness and appropriateness of the final amendments and, more importantly, on the possibility that the reform proposals published by National Treasury in February 2016 not included in the final amendments will be enacted in the future. This investigation will assist tax practitioners and taxpayers in effective tax and estate planning, given that the reform proposals and final amendments have a possible impact on the future of discretionary trusts in South Africa.

Setting: This article examines existing literature in a South African income tax environment.

Methods: In order to meet this objective a qualitative approach based on a literature study of pure theoretical aspects was used.

Results and conclusion: It was found that should the reform proposals become law, many trusts would become ineffective from a tax-planning perspective and these changes might erode other benefits trusts offer, jeopardising the future of discretionary trusts in South Africa.

\section{Introduction}

\section{Background and formulation of the study}

Trusts have long been associated with elaborate tax avoidance schemes, and there exists a perception that trusts are misused by wealthy South Africans (BDO 2013). For tax purposes trusts are being used as an estate planning mechanism, including the avoidance of estate duty and donations tax. The founder of a trust would typically transfer assets to the trust by selling these assets to the trust and granting an interest-free (or low-interest bearing) loan. The founder of the trust will not be liable for donations tax because the assets are sold to the trust, and the assets so transferred will not be included in the founder's estate at death (Mazansky et al. 2016; Treasury 2016a:49). An interest-free loan is also not regarded as a donation for donations tax purposes (Strydom 2008). According to Cecil Morden, the chief director of economic tax analysis at National Treasury, the avoidance of tax is further exacerbated by the founder not receiving interest - on which tax is payable - and the value of the loan being eroded by the time value of money (Du Preez 2016). In terms of the 'conduit principle', income or capital that is realised inside a trust can 'flow-through', or be distributed to the beneficiaries of the trust, while retaining the nature of the income, resulting in the income or capital being taxed in the hands of the beneficiary and not in the trust (Stiglingh et al. 2016:845). The consequent tax advantage is that the natural person beneficiary qualifies for the limited interest exemption in terms of section 10(1)(i) of the Income Tax Act No. 58 of 1962 (Act) and the annual capital gains tax exclusion.

The topic of trust reform first featured in the 2012 National Budget [South African Institute of Tax Practitioners (SAIT) 2013]. The South African Revenue Service (SARS) Strategic Plan (2012/13-2016/17) states that an analysis shows that a significant number of high-net-worth

Note: This article follows 'Part 1', namely: Brink, S.M. \& Willemse, L., 2014, 'An investigation into the future of discretionary trusts in South Africa - An income tax perspective', Journal of Economic and Financial Sciences 7(3), 795-816, available here: http://journals.co. $\mathrm{za} /$ content/jefs/7/3/EJC164675\#abstract_content. 
individuals (HNWIs) are under-declaring their income (SARS 2013:19) and that trusts are used as a means of avoiding tax (SARS 2013:33), resulting in significant revenue losses (SARS 2013:19). It also stated that under-declaration of income by persons in the HNWI category was wide-spread with 'only a fraction' actually declaring their income to the SARS. The Strategic Plan announced that trust reform would be prioritised. No further detail was given at that stage of what the reform proposals might entail.

During the 2013 National Budget the Minister of Finance indicated that Government was proposing several legislative measures during 2013/2014 regarding trusts to control abuse. The Minister of Finance also stated that 'various measures [will be] proposed to protect the tax base and limit the scope for tax leakage and avoidance'. One such measure was that 'the taxation of trusts will come under review to control abuse' (Gordhan 2013:21). The National Budget review document (Chapter 4) shed some light on what these proposals entail and include the following:

Discretionary trusts should no longer act as flow-through vehicles. Taxable income and losses (including capital gains and losses) should be fully calculated at trust level with distributions acting as deductible payments to the extent of current taxable income. Beneficiaries will be eligible to receive tax-free distributions, except where they give rise to deductible payments (which will be included as ordinary revenue). (Treasury 2013:54)

The implication of the above proposal can be summarised as follows: The conduit pipe principle is under review as the proposals state that trusts should no longer act as a flowthrough vehicle, meaning that the amounts distributed to the beneficiaries will no longer retain their original identity (BDO 2013) and that a trust should be taxed as a separate and distinct entity (Croome 2013). The proposals suggest that taxable income or losses and capital gains or losses will be taxed in the trust, with distributions acting as deductible payments to the extent that there is current taxable income. A trust will therefore only be able to distribute 'taxable income'. If the trustees of a discretionary trust exercise their discretion to distribute amounts to beneficiaries in the same year of assessment in which the amounts are received or accrued, a normal income tax calculation for the trust needs to be carried out. The taxable income of a trust must be calculated by including all receipts and accruals (certain of these receipts and accruals may be exempt from tax, for example local dividends), claiming certain expenses as deductions and including any taxable capital gain. The result of this calculation should be the theoretical taxable income of the trust if no distributions were to be made and none of the receipts and accruals vested in any beneficiaries during that same year of assessment. After calculating the taxable income of the trust, the trustees can make distributions to the beneficiaries. Once the amount of taxable income has been distributed out of the trust, the amount will be subject to tax in the hands of the beneficiary and not in the trust. Any distributions to beneficiaries would therefore be treated as a deductible payment by the trust and the beneficiary would then be taxed thereon as having received ordinary income (the effect of the income not retaining its original identity). The proposed amendments therefore directly disqualify the beneficiary from making use of both the basic interest exemption and the capital gains tax concessions available to a natural person.

It was expected that the trust reform proposals would be included in the 2013 draft Taxation Laws Amendment Bill and Tax Administration Laws Amendment Bill (issued in July 2013) as the draft legislation usually gives effect to tax proposals announced during the Budget Review. The draft legislation however did not include any trust reform information or specifics, which resulted in National Treasury indicating that the trust reform proposals required more consultation and would be dealt with later in 2013 or as part of 2014's process (Treasury 2013). After the issue of the Bills the Minister of Finance mandated the Davis Tax Committee (DTC) 'to assess our tax policy framework and its role in supporting the objects of inclusive growth, employment, development and fiscal sustainability' (Citadel Wealth Management 2016).

The 2014/2015 and 2015/2016 National Budget did not include any reference to the above-mentioned proposals. The only change to the taxation of trusts was the increase in the income tax rate from $40 \%$ to $41 \%$ for years of assessment beginning on or after 1 March 2015. The first mention of trust reform proposals after the 2013 National Budget was found in the DTC's first interim report on estate duty (January 2015). In this report the DTC made certain recommendations in order to address many deficiencies of the current estate duty system, including the following (DTC 2015): The deeming provisions of section 7 and 25B of the Act should be repealed, insofar as they apply to Republic of South Africa (RSA) resident trust arrangements and trusts should be taxed as separate taxpayers. The DTC explained that the provisions of sections 7 and 25B of the Act allow the trustees of a trust to cause the trust income to vest and be taxed in the hands of a beneficiary. This is known as the 'attribution principle'. The attribution rules in section 7 were originally intended as an anti-avoidance measure aimed at preventing a trust from being used as an income splitting device. However, today the attribution rules are employed to avoid tax, thereby subverting the very purpose for which they were introduced. In order to avoid the donations tax implications of implementing an inter vivos trust arrangement, many assets are transferred into trusts, allowing the transfer consideration to remain outstanding by way of an interest-free loan account.

In December 2015, the Citadel Fiduciary team attended a SAIT webinar on the first interim report on estate duty of the DTC, presented by Judge Davis. The Judge indicated that there had been some changes in the DTC's views because it received responses to the first interim report. Judge Davis stated that trusts were not dealt with correctly in the first interim report and that the conduit principle would probably remain in respect of distributions from local trusts made in the year of assessment. This is consistent with the industry 
feedback on the initial recommendations (Citadel Wealth Management 2016).

Trust reform proposals were again a topic during the 2016 National Budget. The National Budget review document (Chapter 4) provides the following detail regarding the rationale behind the proposals:

An important role of the tax system is to reduce inequality. Some taxpayers use trusts to avoid paying estate duty and donations tax. For example, if the founder of a trust sells his or her assets to the trust, and grants the trust an interest-free loan as payment, donations tax is not triggered and the assets are not included in his or her estate at death. To limit taxpayers' ability to transfer wealth without being taxed, government proposes to ensure that the assets transferred through a loan to a trust are included in the estate of the founder at death, and to categorise interest-free loans to trusts as donations. Further measures to limit the use of discretionary trusts for incomesplitting and other tax benefits will also be considered. (Treasury 2016a:49)

The 2016 draft Taxation Laws Amendment Bill and the final Amendment Bill ('Amendment Bill') did little to include any of the above-mentioned proposals, but shifted focus to introduce rules on interest-free loans or loans with interest below market rates to limit taxpayers' ability to transfer wealth to a trust without being subject to tax (Treasury 2016d). The following rate changes were also included in the 2016/2017 National Budget speech: The inclusion rate for capital gains will increase from $66.6 \%$ to $80 \%$, resulting in an increase in effective rate from $27.3 \%$ to $32.8 \%$ (effective for years of assessment beginning on or after 1 March 2016).

On 24 August 2016, the DTC released its second interim report on estate duty. The following recommendations were made based on the DTC's investigations and observations (Davis Tax Committee 2016): The conduit pipe principle should be retained for vested trusts and for discretionary trusts only insofar as the trust deed confers upon its beneficiaries an indisputable and irrevocable vested right to both the capital and income of a trust. The flat rate of taxation of trusts (currently 41\%) should be retained and be subject to adjustments in line with changes to the maximum personal income tax rate. Trust arrangements should also be examined by the SARS on registration of the trust and upon transfer of assets into trusts so as to, inter alia, reduce aggressive taxplanning. Donors and beneficiaries of all vested trusts should be subject to stricter disclosure requirements and enforcement measures. The DTC also recommends extending the provisions of section 3(3)(d) of the Estate Duty Act No. 45 of 1955 (Estate Duty Act) by expanding the meaning of 'deemed control'. The DTC suggests that section 3(3)(d) will apply in the following scenario:

- Where a loan account exists between a trust and a 'connected person(s)',

- The loan is not subject to interest, or is subject to interest at below the official rate of interest,

- The holder of the loan can demand repayment within a specified period, and
- The holder of the loan will be deemed to be in effective control of the trust.

The holder of the loan account would then be subject to annual taxation on interest paid on the loan account (at least the official rate of interest) and the trust arrangement would be devoid of any estate duty advantage owing to the application of section 3(3)(d).

\section{Literature review}

Brink and Willemse (2014:795-816) investigated the future of discretionary trusts in South Africa given the 2013 National Budget trust reform proposals. The research problem was derived from the fact that the proposals, at that stage, were vague and confusing and that no effect was given to the proposals in the Amendment Bills, leaving taxpayers, tax practitioners and the general public uncertain and confused as to what exactly the proposals are and what the future of trusts in South Africa might be (Brink \& Willemse 2014:796). The main objective of their research was to clarify the 2013 proposed changes to the taxation of trusts, to investigate the potential impact(s) of these proposals (albeit unclear and consequently based on certain assumptions), and to assess whether discretionary trusts still have a future in South Africa given these proposals (Brink \& Willemse 2014:797).

From the literature review Brink and Willemse (2014:803) identified two possible interpretations of the reform proposals mentioned in the 2013 National Budget speech:

- The scrapping of the conduit pipe principle would mean that the amounts distributed to the beneficiaries will no longer retain their original identity and those amounts will be income in nature in the hands of the beneficiary. The beneficiary therefore does not qualify for the basic interest exemption and the capital gains tax concessions available to a natural person. Any distributions to beneficiaries would be treated as a deductible payment by the trust to the extent that there is current taxable income.

- A trust should be taxed as a separate and distinct entity meaning that a trust would be liable to pay tax in its own right without the possibility of passing income and capital gains through to beneficiaries. Therefore, irrespective of whether the trustees exercise their discretion or not, amounts received by the trust will be taxed in the trust's hands and distributions made to beneficiaries would be tax-free in their hands (Brink \& Willemse 2014:812).

The article also made use of practical examples (a trust receiving interest, dividends and proceeds from the disposal of a capital asset) to illustrate the impact of the proposals. Brink and Willemse (2014:804-808) compared the current tax position with the proposed tax position, for both the trust and the beneficiary, for Interpretation 1 and Interpretation 2 . The tax effect of the proposed amendments in a scenario where the trustees decide to distribute all of the receipts and accruals (the interest, dividends and capital gain) in the trust 
to the beneficiary is an alarming increase of almost 200\% for Interpretation 1 and $320 \%$ for Interpretation 2 in the overall income tax liability (for the given example illustrated in the article). The current and proposed tax position is the same in a scenario where the trustees decide not to distribute any of the receipts and accruals in the trust to the beneficiary (for Interpretation 1 and Interpretation 2) (Brink \& Willemse 2014:804-808). Brink and Willemse (2014:811) state that the current legislation regarding the taxation of discretionary trusts in South Africa is sufficient and that a more effective application of current anti-avoidance rules and mechanisms by the SARS would discourage taxpayers from abusing trusts. To punish discretionary trusts in the manner proposed therefore seems exaggerated and unnecessary given the current legislation and the structures available to the revenue authority at present (Brink \& Willemse 2014:811-812).

The article referred to above highlights that should the radical proposed amendments be applied the use of a discretionary trust might become extremely unfavourable. The article subsequently explains the procedure that should be followed to terminate a trust as well as the possible tax effect should a trust be terminated (Brink \& Willemse 2014:812). Brink and Willemse (2014:813-814) recommend that National Treasury should scrap these proposed amendments in order to ensure and promote equitability and that the SARS should rather apply current anti-avoidance rules more efficiently and strictly.

\section{Research problem}

The dynamic of discretionary trusts has changed drastically since 2012, when trust reform first became a topic, and there is uncertainty regarding whether or not a discretionary trust is still an effective vehicle to use for minimising overall tax liability.

\section{Research objective and methodology}

'An investigation into the future of discretionary trusts in South Africa - an income tax perspective [Part 1]' investigated whether discretionary trusts have a future in South Africa, given the 2013 National Budget reform proposals. Part 2, this article, is based on research that investigated whether discretionary trusts have a future in South Africa, given the new developments since 2013. The trust reforms as announced in the 2016 National Budget speech as well as the amendments will possibly have an impact on the future of discretionary trusts in South Africa. Therefore, the research aimed firstly to clarify what exactly the taxation of trusts reforms as announced in the 2016 National Budget speech are and secondly what the potential effect or impact of these proposals could be. The possible impacts are based on the assumptions applied in the clarification process found in the section Clarification of the taxation of trust reform proposals of this article. These proposals can then be compared with the amendments, contained in the Amendment Bill, to determine the fairness and appropriateness of the amendments and more importantly - the possibility that the proposals not included in the amendments might still be enacted in the future. In order to meet the main objective, the research considered how the dynamic of trusts has changed and compares the position of trusts, without the tax benefits currently in jeopardy under reform proposals, with other benefits a trust offers. In summary, the potential problems associated with the taxation of trusts reforms are highlighted and the result of the investigation could assist tax practitioners and taxpayers in effective tax and estate planning. Relevant issues for future consideration are therefore identified to potentially assist the taxpayer in deciding whether a discretionary trust is appropriate for his or her objectives and needs.

The research made use of a qualitative approach based on a literature study of pure theoretical aspects. A documentary analysis was used as the research method. Hutchinson and Duncan (2012:101) describe the research strategy followed (which is doctrinal in nature) as research which provides a systematic exposition of the rules governing a particular legal category, analyses the relationships between rules, explains areas of difficulty and, perhaps, predicts future developments.

The problem-based doctrinal research methodology applied in the research included the following steps (Hutchinson \& Duncan 2012:106):

- gathering of all relevant and applicable facts

- identification of the specific requirements

- analysis of the issues from a legislative perspective

- studying of sources such as academic text books, journal articles as background

- the identification of primary sources including case law and legislation

- synthesising of all the relevant issues within the correct context

- the drawing of an effective and sensible conclusion.

Bearing in mind the above-mentioned steps, the article is structured as follows:

- literature review of the topic at hand

- a concise discussion on the current income tax treatment of trusts in South Africa

- a discussion of the benefits and costs of establishing a trust

- clarification of the taxation of trusts amendment proposals

- practical example of the potential implications of the proposed taxation on trusts amendments

- a comparison of the amendments contained in the Amendment Bill with the National Budget reform proposals

- summary, conclusion and recommendations.

\section{Scope and limitations of the study}

The research on which this article is based focused exclusively on the potential impacts of the reform proposals and final amendments in respect of a discretionary trust. 
Furthermore, in the study, consideration was given only to ordinary trusts. Special trusts are therefore excluded from the scope of this article.

\section{Current income tax treatment of trusts in South Africa}

As stated in the scope and limitations section above, the income tax treatment of special trusts is not discussed in this article. The article therefore focuses on an ordinary trust that, by default, is a trust which is not a special trust as defined in the Act. Special trusts are taxed at the rates applicable to individuals. The tax rate for an ordinary trust is fixed at $41 \%$ (Treasury 2016b) of taxable income - representing the highest rate of tax. A trust is also taxed at the highest rate for capital gains purposes. With effect from 1 March 2016 an inclusion rate of $80 \%$ is applied to a net capital gain of a trust, causing a taxable capital gain in the trust, which will be subject to tax at $41 \%$, resulting in an effective rate of capital gains tax of $32.8 \%$. According to Haupt (2016:893), there are two types of ordinary trusts, namely a testamentary trust (this is a trust created in terms of a will) and an inter vivos trust (this is a trust created by contract during the lifetime of the creator). In each of these trusts there are two types of rights a beneficiary can have:

- a vested right - which means that either the income or the capital of the trust must be paid to the particular beneficiary. The trustees therefore merely administer the capital or income for the beneficiary

- a contingent right - which means that no particular beneficiary is entitled to any income or capital unless the trustees decide to make a distribution to the beneficiary. In this case there is a chance that the beneficiary will never receive any portion of the income or capital in the trust (Haupt 2016:893).

In the first-mentioned instance (a vested right), the trustees administer the capital and income for the beneficiaries as a group with no certainty as to which beneficiaries will ultimately benefit from the funds in the trust, and to what extent (Haupt 2016:893).

Section $25 B$ provides that (subject to section 7 ) the income of the trust is taxed either in the trust or in the hands of the beneficiaries if that beneficiary has a vested right to the amount (for example in terms of the trust deed) (Haupt 2016:811; Stiglingh et al. 2016:848). With regard to a discretionary trust, section $25 \mathrm{~B}(2)$ states that the exercise of the trustees' discretion qualifies as a vesting event. This means that if a person did not have a vested right in terms of the trust deed, vesting will occur when the trustees decide to make a discretionary distribution to a specific beneficiary (Stiglingh et al. 2016:848).

The same result is achieved for capital gains tax purposes by applying paragraph 80(2) of the Eighth Schedule to the Act. Paragraph $80(2)$ is applicable when a beneficiary acquires a vested interest in a capital gain (as a result of the trustees exercising their discretion to distribute the gain) made by the trust on the disposal of an asset. Paragraph 80(2) states that (subject to paragraphs 68, 69, 71 and 72) in this scenario the capital gain vesting in the beneficiary must be disregarded in the trust but taxed in the hands of the beneficiary in whose hands the gain vests.

Section 7(1) applies where the beneficiary has a vested right to the income retained in the trust. In other words, the beneficiary is certain to receive the income at some time in the future; only his enjoyment of it has been postponed. If he dies before the income is paid to him, it will go to his estate. Therefore, as the income is effectively the beneficiary's, he will be taxed on it (Haupt 2016:817).

\section{Benefits and costs of establishing a trust}

When an individual considers whether or not to make use of a discretionary trust, the benefits a trust offer will typically be compared with the costs associated with the establishment and management thereof. In answering the question whether discretionary trusts have a future in South Africa, a distinction must be made between the benefits currently in jeopardy under reform proposals and amendments and other benefits a trust offers. Each individual's objectives and needs will differ, and these objectives and needs will determine whether or not an individual deems a discretionary trust to still be cost-effective and whether or not an individual will still make use of a discretionary trust given the reform proposals and suggested amendments.

\section{Benefits trusts offer individuals}

\section{Current tax benefits trusts offer currently in jeopardy under reform proposals}

According to Hill (2012), trusts are commonly used to 'freeze' the value of assets where a natural person does not want the assets to form part of his deceased estate. The founder of a trust will usually sell his assets to the trust at market value on an unsecured, interest-free loan (Mazansky et al. 2016). The loan will be included in the founder's estate at death, but the further growth in the value of the assets will accrue to the trust. The effect is to reduce the dutiable estate of the seller over time (by not including any further growth in the value of the assets) and effectively the estate duty (levied at $20 \%$ on the net value of an individual's estate) arising upon his death as well. This ultimately results in the heirs receiving a larger inheritance (Hill 2012). The founder can also reduce the loan by annually donating to the trust the maximum amount of R100 000 that a natural person can donate, under the general exemption (section 56(2)(b) of the Act), without triggering donations tax. By the time the founder dies, the loan that should be included in the founder's estate is either greatly reduced or written off (Du Preez 2016).

Another reason for accumulating assets in a trust is the deceased's potential liability for capital gains tax. For capital gains tax purposes a deceased person is deemed to have 
disposed of his assets to his deceased estate for proceeds equal to its market value at the date of his death (paragraph 40 of the Eighth Schedule to the Act or section 9HA(1) for persons who die on or after 01 March 2016). The founder would have been liable for capital gains tax on the initial disposal of the asset to the trust at the date of the disposal, but the further growth in the value of the assets will accrue to the trust and will therefore not be subject to capital gains tax at the date of the founder's death. The deceased founder will also not be liable for capital gains tax on the deemed disposal of the loan because the base cost of the loan should not be less than the market value of the loan (Warneke 2016a). When considering donations tax on the transaction the following is applicable: The founder will not be liable for donations tax, at a flat rate of $20 \%$, because the assets are sold (given that they are sold at market value) to the trust (Treasury 2016a:49).

The conduit pipe principle, as codified in section 25B of the Income Tax Act, applied to trusts offers a further advantage with regard to potential tax savings. In Armstrong v CIR (1938) it was determined that income of a trust retains its identity until it reaches the parties (beneficiaries) in whose hands it is taxable. A trust is therefore a mere conduit pipe through which the income flows, meaning that if income accrues to a trust and the trustees distribute it to one or more beneficiaries in the same year, the income retains its nature in the hands of the beneficiary (Holdstock 2013). The trust law therefore provides for income splitting opportunities (Holdstock 2013) - this provides the main reason why trusts can be used efficiently for income tax purposes.

Based on the conduit or flow-through principle when the accrual of the income is to a beneficiary, any exemption from tax provided in the Act applying to the income will be available to that beneficiary. For example, if the beneficiary receives local dividends as a distribution from the trust, the section 10(1)(k) exemption will be available to the beneficiary. If the beneficiary receives interest as a distribution from the trust, the beneficiary will be entitled to the section 10(1)(i) exemption (currently R23 800 for taxpayers under 65 and R34 500 for taxpayers 65 and above for the 2017 year of assessment) (Treasury 2016b). If a beneficiary receives a distribution of capital gain, the income will not be treated as ordinary income but will retain its identity as a capital gain (applying paragraph 80(2) of the Eight Schedule to the Act). The capital gain will be included at the inclusion rate of $80 \%$ in the beneficiary's taxable income after deducting the annual capital gains tax exclusion of R40 000 (for the 2017 year of assessment) (Treasury 2016b). Natural persons can therefore benefit from the tax exemptions related to the income derived from a specific asset class, while housing the said assets in a trust.

A trust can therefore be used to avoid tax. It is important to distinguish between tax avoidance and tax evasion, the latter referring to illegal activities deliberately undertaken by a taxpayer to free himself from a tax burden. Tax avoidance, by contrast, is where the taxpayer has arranged his affairs in a perfectly legal manner, resulting in a reduced tax liability
(Stiglingh et al. 2016:811). Tax avoidance does therefore not constitute tax evasion and it is a trite rule of tax law that taxpayers are allowed to order their tax affairs in the manner that gives them the best advantage (CIR v Conhage [Pty] Ltd. [1999]). The Act contains various provisions that are designed either to prevent or to counter specific schemes or operations aimed at the avoidance of tax. A discussion of specific antiavoidance provisions contained in the Act that are applicable to the misuse of trusts follows.

Section 7(2) to 7(8) of the Act and paragraphs 68 to 72 of the Eighth Schedule to the Act are anti-avoidance provisions aimed at taxing, in the hands of the donor, any income and capital gains which have resulted from a donation, settlement or other disposition, even though a beneficiary has a vested right to an amount or has actually received it (Stiglingh et al. 2016:849,942). It is important to note that these provisions are not concerned with who formed or created the trust but rather with the person who transferred assets into the trust. These provisions effectively seek to tax the person who introduced the assets into the trust on the income or capital gain generated by those assets (Haupt 2016:812). Section 7(2) to 7(8) and paragraphs 68 to 72 of the Eighth Schedule to the Act may only be invoked if a 'donation, settlement or other disposition' has taken place (Stiglingh et al. 2016:850, 943). In Ovenstone V SIR (1980) it was held that the expression 'donation, settlement or other disposition' should be read as 'donation, settlement or other similar disposition'. The word 'disposition' was interpreted to mean any disposal of property made wholly or to an appreciable extent gratuitously out of the liberality or generosity of the disposer. An interestfree loan, being a gratuitous disposal, can therefore be seen as a 'donation, settlement or other disposition' for purposes of section 7(2) to 7(8) (Stiglingh et al. 2016:850). The deemed interest, calculated by using a market-related interest rate, indicates the maximum amount that may be attributed to the donor should income accrue that is subject to section 7(2) to 7(8) (Stiglingh et al. 2016:855). Paragraph 73 of the Eighth Schedule to the Act further limits the total amount of the section 7 income that is deemed to accrue to the donor plus the capital gain attributed to him in terms of the attribution rules of the Eighth Schedule to the Act.

Therefore, in the scenario described above the income or capital gains derived from the assets transferred to the trust through an interest-free loan can also be distributed to beneficiaries (excluding scenarios as described in section 7(2) to (8) and paragraphs 68 to 72 ) resulting in the income or capital gains being taxed in the hands of the beneficiaries and not in the hands of the donor or the trust.

Section 3(3) of the Estate Duty Act provides for certain property to be deemed property of the deceased estate. Section 3(3)(d) of the Estate Duty Act determines that property that the deceased was competent to dispose of for his own benefit or for the benefit of his estate immediately prior to his death is deemed to be property in his estate. Section 3(5)(b) explains the meaning of 'competent to dispose of any property' for purposes of section 3(3)(d) as 
that the deceased had the power that would enable him to dispose of such property. Stiglingh et al. (2016:1008) give the following example to explain the meaning of section 3(3)(d) in the context of a trust: If the deceased was the sole trustee and a beneficiary of a trust, he could be considered to have had the power to dispose of the property of the trust for his own benefit. Because he had the right to dispose of the property for his own benefit, the property of the trust would be deemed property in his estate, even if he did not exercise that right.

An interest-free loan can be seen as a 'donation, settlement or other disposition' for purposes of section 7(2) to 7(8) and paragraphs 68 to 72 of the Eighth Schedule to the Act but not necessarily a donation for the application of donations tax (Stiglingh et al. 2016:850). Section 54 of the Act determines that donations tax is payable on the value of any property disposed of by a South African resident in terms of a donation. The definition of 'property' includes any right in or to property (section 55(1) of the Act). For purposes of determining whether an interest-free loan constitutes a donation for donation tax purposes, it has to be established whether the lender had any 'right' to interest, which is gratuitously waived. The loan agreement will determine whether a right to interest exists. If the loan agreement provides for interest and the lender waives that right stipulated in that agreement, a gratuitous waiver would result and would therefore be regarded as a donation. However, if no provision is made for interest in the agreement, no inherent right to interest arises, and there can be no waiver of any right to interest and no donation will arise (Stiglingh et al. 2016:827). Strydom (2008) also states that it is not the practice of the SARS to treat an interest-free loan as a donation for donations tax purposes. The only other way that donations tax will be triggered is if the granting of the loan led to a deemed donation in terms of section 58, which stipulates that if property is disposed of for a consideration which is inadequate, it may be deemed to be a donation.

\section{Other benefits}

Hill (2012) states that there are seven main reasons for establishing a trust:

- Trusts offer protection against other types of tax. Should the deeming provisions in section 7 of the Act not apply, tax savings might be available. For example, income and capital gains can be distributed to trust beneficiaries who might fall under a lower tax bracket than the original owner of the assets. Furthermore, if the trustees do not wish that beneficiaries use the cash immediately (for various reasons), income and gains can be vested in such beneficiaries and physical payment made later, for example, at a time when they reach an age of understanding, or the monies are needed to fund education.

- Trusts can reduce the costs of winding up a deceased estate. Executor's fees and other winding up costs can reduce the available cash balance in an estate. Trusts do not die and would therefore not incur such costs.
- Trusts offer protection against the uncertainties of life. Trusts offer protection against claims arising against a personal owner of assets during his lifetime. At death, compensation in the form of life assurance proceeds is usually available, but during life, a large claim against one's estate, possibly leading to personal sequestration, results in no assurance compensation. A trust is consequently a useful risk management tool.

- Trusts offer protection against the uncertainties of death. Trustees who are skilled in financial planning and wealth management can materially enhance the longterm financial well-being of current and future generations.

- Trusts can buy time. The winding up process of an estate could be a lengthy process which can take 6-8 months or even longer. During this time, a business owned personally by the deceased, or a company of which he was the sole director, is at risk. In such circumstances, normal commercial decision-making is suspended, which can lead to customer shrinkage and a potential drop in the value of business assets. Should the deceased's business have been placed in a trust beforehand, no such time constraints are applicable. It also makes more sense to reduce one's personal assets and liabilities to manageable portions, while building up trust assets which the trustees can continue to manage after a person's death, unconstrained by legislated timetables.

- Trusts can mitigate or avoid the common shortfalls in cash in a deceased estate. Most estates require the executor to sell assets to generate sufficient funds to discharge debt. The timing of the sale is not a luxury available to the executor and so, quite often, valuable assets realise far less on a forced sale than they would under normal circumstances. This means that even more assets have to be sold (again at lower prices) to make up any shortfalls.

- Trusts permit one owner, many users. Management, registration, accounting, expense and financial records can be centralised, thus saving costs, while trust beneficiaries can enjoy the advantages of ownership on an equitable basis.

\section{Costs related to the establishment and management of a trust}

The cost for the establishment of a trust is currently in the vicinity of R7500 (Rall-Willemse 2016). A trustee is not automatically entitled to compensation, but trustees are often lawyers or other professionals who cannot afford to work for free. Therefore, a trust deed usually makes provision that trustees are entitled to reasonable payment for their work (Sebenza 2013). Trustees' fees could therefore vary from trust to trust. Depending on the nature and extent of the activities of the trust, additional costs such as administration or management fees, accounting fees and legal fees might also be incurred. Finally, a trust (other than a special trust) is taxed at a flat rate of $41 \%$ and its inclusion rate for purposes of capital gains tax is $80 \%$ (for the 2017 year of assessment). 


\section{Clarification of the taxation of trust reform proposals}

The 2016 reform proposals can be summarised as follows: Assets transferred through a loan to a trust will be included in the estate of the founder at death, interest-free loans to trusts will be categorised as donations and further measures to limit income splitting and other tax benefits will also be considered. These reform proposals are cryptically worded (Warneke 2016a) and very unclear (Du Preez 2016); therefore, the following section of the article aims to clarify these vague proposals. The interpretation of the proposals can then be compared with the amendments included in the final Amendment Bill. This might shed some light on the thought process behind the amendments included and provide some insight on whether or not the proposals not included in the amendments might become law in the future.

Warneke, tax partner at BDO SA, is of the opinion that there was an error in the wording of the first proposal in that it meant to say that it is the disposer (seller) of the assets who would be taxed, rather than the founder of the trust (Warneke 2016a). Assuming that this is the case the following is applicable: The total value of the assets transferred through a loan to a trust will be included in the estate of the disposer at death. Cecil Morden, the chief director of economic tax analysis at National Treasury, explains that the disposal of an asset to a trust on a loan account will not be deemed a disposal for estate duty purposes, meaning that the total value of the asset (including the growth in the value of the asset) will be taxable in the deceased estate (Du Preez 2016). It is important to note that the proposal states that the value of the assets will be included in the estate of the disposer and not that the value of the assets will form part of the disposer's assets at date of death. The effect is that the disposer will not be deemed to have disposed of these assets at market value to the deceased estate (paragraph 40 of the Eighth Schedule to the Act or section 9HA(1) for persons who die on or after 1 March 2016) for purposes of capital gains tax. Section 5 of the Estate Duty Act will then determine the value of the assets included in the estate for estate duty purposes. Also note that the first proposal refers to a loan, meaning any loan, be it interest-free or interest bearing. Treasury is also considering including the interest-free loan in the estate of the person who grants the loan (Du Preez 2016). Treasury says this is 'another option' seeing that it suggests that the disposer will be taxed twice on the amount transferred to the trust (Du Preez 2016).

Warneke (2016a) is of the opinion that only the growth in the asset from the date of initial transfer into the trust will form 'deemed property' in the estate of the deceased for purposes of estate duty. This interpretation means that the value of the asset's growth together with the outstanding balance of the loan at the date of death of the disposer will form part of the dutiable estate of the disposer for estate duty purposes. Warneke (2016a) believes an alternative to the above interpretation is that the full market value of the asset will be included in the dutiable estate of the deceased and that the loan will be disregarded as an asset in the hands of the disposer.

Morden interprets the categorising of the interest-free loan as a donation to mean that the lender will pay donations tax at $20 \%$ (after the donations tax exemption of R100 000) of the value of the asset moved to the trust. It is important to note that this proposal specifically refers to an interest-free loan, meaning that as long as the trust pays interest on the loan, donations tax will not be triggered. It is not necessary for the interest that accrues on the loan to be paid in cash; an alternative is to capitalise the interest against the loan account, which then grows accordingly in the estate of the lender ( Du Preez 2016). Morden argues that an alternative proposal to making the interest-free loan a once-off donation is to deem the income the lender has received on the loan, had interest been charged, to be an ongoing donation, to which donations tax and, potentially, income tax will apply. This alternative proposal is in line with Harbour and Associates' (2016) opinion that the proposal will probably be modified to state that only the deemed interest is treated as a donation rather than the initial loan itself. A similar amendment was made with regard to loans made by companies to directors and their original treatment as dividends. This amendment was subsequently amended to treat only the deemed interest as a dividend (Harbour and Associates 2016). Warneke (2016a) is also of the opinion that it is the non-charging of interest that would be regarded as a donation rather than the entire capital amount of the loan. To regard capital lent as a donation is inconsistent with the meaning of the word 'donation', as it is an amount that has to be repaid. Warneke (2016a) states that the proposal may be formulated in such a way that, regardless of the terms of the loan, the non-charging of interest will be regarded as a donation for purposes of donations tax. One possibility is that donations tax will be levied annually at the rate of $20 \%$ on a market-related interest rate applied to the outstanding balance on the loan (Warneke 2016a).

It appears that treating the loan as a donation subject to donations tax and also including the trust's assets as assets of the founder's estate at death for estate duty purposes would amount to double counting (Mazansky et al. 2016). In order to avoid double taxation, either the asset or loan or the donations tax on the asset or loan will be taken into account in determining the estate duty due on the asset (Du Preez 2016).

There is uncertainty whether or not these proposals, to the extent that they are not given effect to in the draft Amendment Bill, will be applied retrospectively (Harbour and Associates 2016) and if not, what steps will be taken to avoid retroactivity (Mazansky et al. 2016). Warneke (2016a) emphasises that the timing of the effective date of the proposed legislation will be very important to monitor and will answer the question of retroactivity. If the proposal becomes effective for assets disposed of to a trust on or after a given future date then it will not have retrospective effect. However, if the proposal applies to trusts on or after a given future date then it will have retrospective effect in that it will apply so as to tax unrealised gains in assets already held in trusts. The constitutionality of 
such a proposal may well be challenged (Warneke 2016a). The 2016 reform proposals once again refer to 'further measures to limit income splitting', indicating that the review of the conduit pipe principle is still on the table. This proposal was discussed in detail in 'An investigation into the future of discretionary trusts in South Africa - an income tax perspective [Part 1]' and therefore excluded from 'Part 2' of the article. The reform proposals are unclear and from the above-mentioned literature four potential interpretations can be attributed to it, namely:

\section{- Interpretation 1}

- The disposer's deceased estate will be liable for estate duty on the full market value of the assets transferred through a loan to a trust.

- The disposer's deceased estate will be liable for estate duty on the outstanding value of the loan.

- The disposer will be liable for annual donations tax on a market-related interest rate applied to the outstanding balance of the interest-free loan and/or,

- The disposer will be liable for annual income tax on a market-related interest rate applied to the outstanding balance of the interest-free loan.

\section{- Interpretation 2}

- The disposer's deceased estate will be liable for estate duty on the growth in the asset from the date of initial transfer into the trust till the date of death of the disposer.

- The disposer's deceased estate will be liable for estate duty on the outstanding value of the loan.

- The disposer will be liable for annual donations tax on a market-related interest rate applied to the outstanding balance of the interest-free loan and/or,

- The disposer will be liable for annual income tax on a market-related interest rate applied to the outstanding balance of the interest-free loan.

\section{- Interpretation 3}

- The disposer's deceased estate will be liable for estate duty on the full market value of the assets transferred through a loan to a trust.

- The disposer's deceased estate will not be liable for estate duty on the outstanding value of the loan (the outstanding loan is disregarded as an asset in the disposer's deceased estate).

- The disposer will be liable for annual donations tax on a market-related interest rate applied to the outstanding balance of the interest-free loan and/or,

- The disposer will be liable for annual income tax on a market-related interest rate applied to the outstanding balance of the interest-free loan.

\section{- Interpretation 4}

- The disposer will be liable for donations tax on the value of the asset transferred through an interest-free loan to the trust.

The following section makes use of a practical example illustrating the probable tax implications of all four interpretations of the reform proposals. The current income tax treatment and the proposed income tax treatment for the scenario are investigated and compared. Tax rates, concessions and exemption thresholds applicable to the 2017 year of assessment are used for the purpose of the example.

\section{Practical examples of the probable implications of the reform proposals}

To illustrate the practical impact of the reform proposals the following scenario is considered: $A B C$ Trust is a discretionary trust. On 1 March 2016 the disposer (a natural person under 65) transferred an asset, with a market value of R1 000000 and a base cost of R500 000, to the trust by selling the asset (at market value) to the trust and granting an unsecured loan. The loan agreement provides for no repayment conditions or interest payable. On 28 February 2026 the disposer dies. On 28 February 2026 the market value of the asset transferred to the trust amounts to R2 000000 and the total value of the loan is outstanding. Assume a market-related interest rate of $10 \%$ for the entire period under consideration. Further assume that section 7(2) to 7(8) of the Act and paragraphs 68 to 72 of the Eighth Schedule to the Act are not applicable in this scenario.

Table 1 illustrates the current tax effect and proposed tax effect per tax type on the disposer's tax calculation per transaction for the given scenario.

Table 2 illustrates current tax effect and proposed tax effect per tax type on the disposer's deceased estate's tax calculation per transaction for the given scenario.

In this scenario where no loan repayments were made, Interpretations 2 and 3 of the reform proposals have the same effect on the disposer's deceased estate's tax calculation. Interpretation 2 includes the outstanding loan and only the growth in the value of the asset in the disposer's deceased estate and Interpretation 3 disregards the outstanding loan but includes the full market value of the asset in the disposer's deceased estate. Ultimately the same value, that is, R2 000000 , is included in the disposer's deceased estate. This same result will only occur when no loan repayments have been made.

The above interpretations of the reform proposals can now be compared with the amendments contained in the Amendment Bill. This comparison will determine the fairness and appropriateness of the amendments and more importantly shed some light on the possibility that the proposals not included in the amendments might still be enacted in the future.

\section{Trust reform proposals versus amendments}

\section{Final amendments}

In order to limit taxpayers' ability to transfer wealth without being subject to tax, the new section $7 \mathrm{C}$ of the Act was 
TABLE 1: Tax effect of the scenario on the disposer's tax calculation: Illustrating the current tax effect and proposed tax effect per tax type on the disposer's tax calculation per transaction for the given scenario.

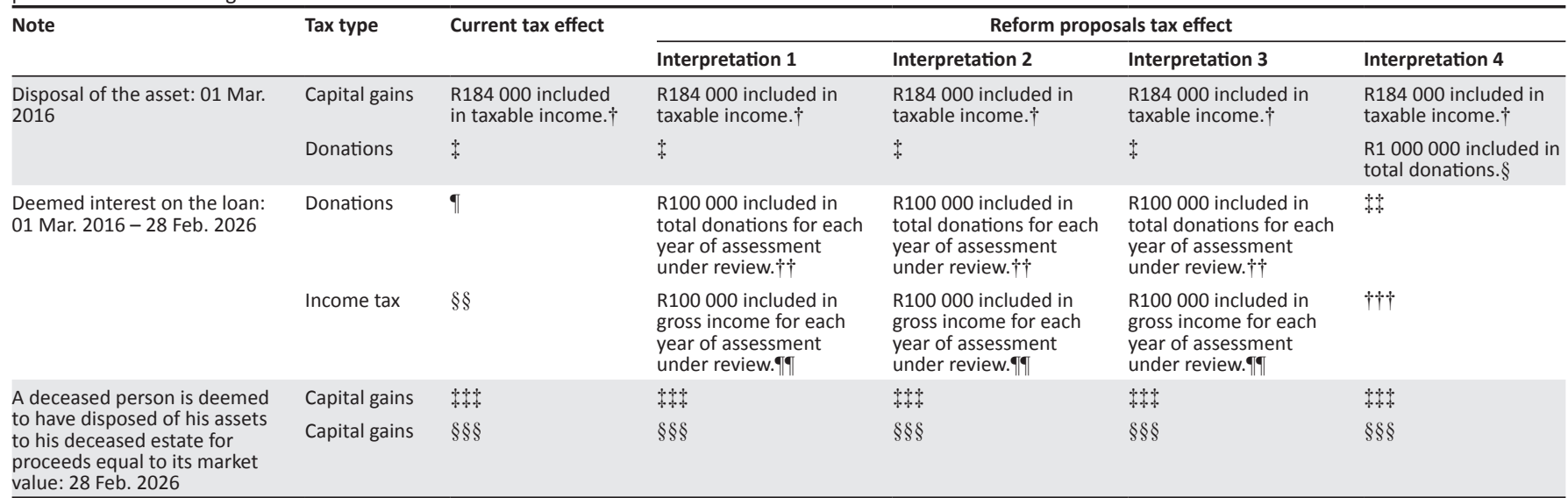

$\dagger$, Section 26A ([R1 000 000-R500 000] - R40 000 annual exclusion) $\times 40 \%$ inclusion rate $=$ R184 000). Normal income tax will be calculated applying the applicable tax rate (per tax table) to the taxable income and then deducting the primary rebate; $¥$, The asset is sold to the trust at market value. Section 58 is not applicable; $\S$, Donations tax will be levied on the value of the asset transferred through an interest-free loan to the trust. Donations tax will be calculated, after deducting the R100 000 general exemption, at a rate of $20 \%$ of the taxable amount; $\uparrow$, The lender had no 'right' to interest, which was gratuitously waived (applying section 55(1) of the Act). No provision is made for interest in the loan agreement, therefore no inherent right to interest arises and there is no waiver of any right to interest and therefore no donations tax on the interest; $\dagger$, Donations tax levied annually on the deemed interest: R1 $000000 \times 10 \%=R 100000$. Donations tax will be calculated, after deducting the R100 000 general exemption, at a rate of $20 \%$ of the taxable amount; $\$$, Donations tax was already levied on the total value of the asset transferred to the trust; $\S \S$, The lender does not receive any interest on the interest-free loan; 9 I, Income tax levied annually on the deemed interest: R1 $000000 \times 10 \%=$ R100 000 . Section 10 (1)(i) interest exemption of R23 800 can be applied against the interest received included in gross income; $++\dagger$, Levying donations tax and income tax on the deemed interest is an alternative proposal to levying donations tax on the total value of the asset transferred to the trust; $+t+$, The market value of the loan equals the base cost of the loan resulting in no capital gain; $\S \S \S$, The asset was originally sold to the trust and is no longer the asset of the disposer at time of death.

TABLE 2: Tax effect of the scenario on the disposer's deceased estate's tax calculation: Illustrating current tax effect and proposed tax effect per tax type on the disposer's deceased estate's tax calculation per transaction for the given scenario.

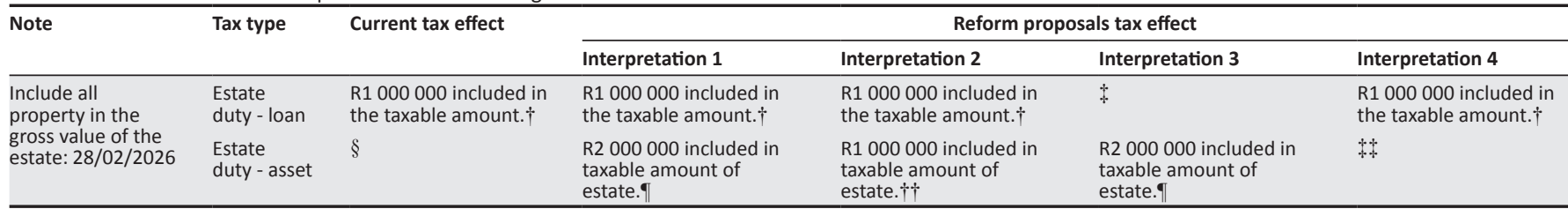

Note: Estate duty will be calculated, after deducting the R3 500000 rebate, at a rate of $20 \%$ of the taxable amount.

$\dagger$, Include the value of the outstanding loan in terms of section 3(2) of the Estate Duty Act; $\$$, Disregarding the outstanding loan as an asset in the disposer's deceased estate and including the full market value of the asset transferred through a loan to a trust in the disposer's deceased estate; $\S$, The asset was originally sold to the trust and is not an asset of the disposer at time of death; I, The asset transferred through a loan to a trust is a deemed property of the estate; $\dagger$, The growth in the asset, from the date of initial transfer into the trust till the date of death of the disposer, is a deemed property of the estate; $\$$, Donations tax was levied on the value of the asset transferred through an interest-free loan to the trust. In order to avoid double taxation the value of the asset is not included in the disposer's deceased estate.

promulgated in respect of years of assessment commencing on or after 1 March 2017 (Treasury 2016d). This section applies if a natural person, or a company in relation to which that natural person is a connected person, makes an interest-free loan or a loan with interest below market rates to a trust. Section 7C determines that interest foregone in respect of low-interest loans or interest-free loans that are made to a trust will be treated as an ongoing and annual donation made by the natural person to the trust on the last day of the year of assessment of that trust. The deemed interest will be calculated as an amount equal to the difference between interest that would arise as determined with reference to the official rate of interest (as determined in terms of the Seventh Schedule to the Act) and the applicable actual rate of the loan below market rates made to a trust. Section 7C also provides that no tax deduction, allowance or loss would be allowed to be claimed by the lender on the waiver or cancellation of an interest-free loan or a loan with interest below market rate (Treasury 2016d). The following tax effect for the lender will be the result of applying section $7 \mathrm{C}$ to the same example used above (refer to the section Practical examples of the probable implications of the reform proposals): Donations tax will be levied annually for each year of assessment under review on the deemed interest of R100 000 (R1 $000000 \times 10 \%=\mathrm{R} 100000)$. Donations tax will be calculated, after deducting the R100 000 general exemption, at a rate of $20 \%$ of the taxable amount.

\section{Comparing the trust reform proposals with the final amendments}

The first trust reform proposal is aimed at stopping the avoidance of estate duty by transferring assets to a trust. The Amendment Bill makes no reference to the proposal of including the assets transferred through a loan to a trust in the estate of the disposer at death. The only amendment contained in the Amendment Bill aiming at countering the avoidance of estate duty is that no deduction is allowed in the case of the cancellation or waiver of an interest-free or low-interest loan. Moving on to the second reform proposal, namely to categorise interest-free loans as donations, the following will be applicable: The Explanatory Memorandum on the Taxation Laws Amendment Bill rules out the proposal of categorising the interest-free loans to trusts as donations (Interpretation 4) by stating that donations tax will not be triggered on an asset when an asset is sold at market value to a trust, because there is no gratuitous disposal as required for donations tax purposes 
(Treasury 2016c:8). To address the avoidance of donations tax section 7C only levies donations tax on the deemed interest (Treasury 2016d). This rules out the interpretation of also levying income tax on the deemed interest.

When comparing the amendments with the interpretations of the reform proposals it is clear that less drastic measures were taken and that trusts got off lightly. Given that trust reform has been a topic since 2012, without any of the previous proposals enacted, these less drastic or minor amendments were unexpected and should set off warning lights. Therefore, there is a possibility that reform proposals not included in the amendments and not specifically ruled out might become law in the future and will therefore have an impact on the future of discretionary trusts in South Africa. Accordingly, the focus now shifts to trust reform proposals not included in the suggested amendments that might be enacted in the future.

\section{Trust reform proposals not included in the amendments}

The following reform proposals not included in the amendments and not specifically ruled out might be enacted in the future: Including the full market value of the assets transferred through a loan to a trust in the disposer's deceased estate or only including the growth in the asset from the date of initial transfer into the trust till the date of death of the disposer in the disposer's deceased estate, and including the outstanding loan in the disposer's deceased estate or disregarding the outstanding loan as an asset in the disposer's deceased estate. It is unlikely that income tax will also be levied on the deemed interest as interpreted from the reform proposals seeing that the amendments provide for donations tax on this amount. Measures to limit income splitting and other tax benefits are also still a possibility for the future.

\section{Summary, conclusion and recommendations}

Trusts offer various tax and other benefits. Many of the tax benefits trusts offer are currently in jeopardy under reform proposals and amendments to taxation laws. Each individual's objectives and needs will determine whether or not an individual deems a discretionary trust to still be costeffective and whether or not an individual will still make use of a discretionary trust given the reform proposals and amendments. In order to assist tax practitioners and taxpayers in effective tax and estate planning, research was conducted on the reform proposals and amendments, given that both have a possible impact on the future of discretionary trusts in South Africa.

In the 2016 National Budget the Minister of Finance indicated that Government was proposing several legislative measures during 2016/2017 regarding trusts to control abuse. The proposals can be summarised as follows: Assets transferred through a loan to a trust will be included in the estate of the founder at death, interest-free loans to trusts will be categorised as donations and further measures to limit income splitting and other tax benefits will also be considered. The 2016/2017 trust reform proposals are cryptically worded, unclear and vague; therefore, an attempt has been made in this article to clarify the proposed changes to the taxation of trusts. The Amendment Bill did not give effect to these proposals, but introduced other less drastic measures to control the abuse of trusts for tax purposes. These measures can be summarised as follows: Donations tax will be levied on the deemed interest of an interest-free loan or a loan with interest below market rates to a trust (Treasury 2016d). Given that trusts have long been associated with elaborate tax avoidance schemes and that trust reform has been a topic for the past 8 years, these less drastic or minor amendments were unexpected and possibly indicate that proposals not included in the amendments and not specifically ruled out might become law in the future. In all likelihood there will be a waiting period to determine the efficiency of the new section 7C before any new legislation is passed, but based on DTC's second interim report it is clear that trust reform is far from over. The proposals that might be enacted in the future are the following:

- including the full market value of the assets transferred through a loan to a trust in the disposer's deceased estate (this will be achieved by expanding section 3(3)(d) of the Estate Duty Act as recommended by the DTC's second interim report) or only including the growth in the asset from the date of initial transfer into the trust till the date of death of the disposer in the disposer's deceased estate

- including the outstanding loan in the disposer's deceased estate or disregarding the outstanding loan as an asset in the disposer's deceased estate

- measures to limit income splitting and other tax benefits referring back to the 2013/2014 reform proposal of scrapping the conduit pipe principle, meaning that the amounts distributed to the beneficiaries will no longer retain their original identity and those amounts will be income in nature in the hands of the beneficiary.

Even though the above reform proposals were not included in the Amendment Bill it is clear from the DTC's second interim report that Treasury is planning to control the abuse of trusts in one way or another in the near future. If and when the reform proposals are enacted many trusts would become ineffective and these changes might erode other benefits trusts offer. A natural person that is making use of a trust or that is planning to make use of a trust should consider the possible impact of the amendments and reform proposals and, based on their own needs and requirements, determine whether or not it is cost-effective to use a trust. Should one decide that the use of a trust is no longer cost-effective, it is important to note that a trust cannot simply be terminated owing to a change in tax legislation. 'An investigation into the future of discretionary trusts in South Africa - an income tax perspective [Part 1]' discussed the procedure to follow to terminate a trust and 
also explains the possible tax effect should a trust be terminated (Brink \& Willemse 2014:812).

Against the background of the summary and conclusion above, the following recommendations are made with regard to the amendments and reform proposals:

- Should the reform proposals be enacted into South African income tax legislation Treasury must consider and clear up the following current uncertainties derived from the reform proposals:

- Should the full market value of the assets transferred through a loan to a trust be included in the disposer's deceased estate or only the growth in the asset from the date of initial transfer into the trust till the date of death of the disposer?

- Should the outstanding loan be included as an asset in the disposer's deceased estate or should the outstanding loan be disregarded?

- Should these proposals be applied retrospectively?

- Alternatively, Treasury should scrap the reform proposals, and to deter taxpayers from abusing discretionary trusts with regard to tax avoidance, the SARS should apply the following current anti-avoidance rules more efficiently and strictly:

- Section 7(2) to 7(8) of the Act and paragraphs 68 to 72 of the Eighth Schedule to the Act, and

- Sections 3 (3)(d) read together with section 3(5) of the Estate Duty Act.

- The SARS should monitor trusts more closely by implementing structures to enforce the registration of existing and new trusts with the Master's Office, by monitoring the submission and accuracy of income tax returns of trusts. The SARS might also consider levying penalties for the non-submission of annual income returns for trusts (Peacock 2016).

Although at this stage there is no finality with regard to the reform proposals, this article could serve as a potential problem or risk indicator for future use. Taxpayers and tax experts alike could use this article as a guideline and additional source to take into consideration when one has to decide whether to make use of a discretionary trust in South Africa.

\section{Acknowledgements Competing interests}

The author declares that she has no financial or personal relationships that may have inappropriately influenced her in writing this article.

\section{References}

Armstrong v CIR, 1938, 10 SATC 1, AD 343.

BDO, 2013, The continued attack on the trust structure, viewed 16 July 2013, from http://www.bdo.co.za/resources/showitemarticle.asp?ResourceSectionld=4\&Re sourceSection Name=Publications\&Resourceld $=7 \&$ ResourceName $=$ Tax $\% 20$ Flash \&lssueld $=401$ \& ContentPagelD $=4$ \&Archive $=$ \&articleid $=399$
Brink, S.M. \& Willemse, L., 2014, 'An investigation into the future of discretionary trusts in South Africa - An income tax perspective', Journal of Economic and Financial Sciences 7(3), 795-816.

CIR v Conhage (Pty) Ltd., 1999, ZASCA 64.

Citadel Wealth Management, 2016, Why the review of trust taxation? viewed 26 May 2016, from https://www.citadel.co.za/Insights/view/840/why-the-reviewof-trust-taxation-

Croome, B., 2013, The future taxation of trusts, viewed 16 July 2013, from http:// www.thesait.org.za/news/130112/

Davis Tax Committee, 2015, First interim report on estate duty, viewed 26 May 2016 from http://www.taxcom.org.za/docs/20150723\%20DTC $\% 20$ First $\% 20$ Interim $\% 20$ Report $\% 20$ on $\% 2$ Estate $\% 20$ Duty $\% 20-\% 2$ For $\% 20$ public $\% 20$ comment $\% 20$ by $\% 2030 \% 20$ September $\% 202015$.pdf

Davis Tax Committee, 2016, Second interim report on estate duty, viewed 13 December 2016, from http://www.taxcom.org.za/docs/20160428\%20DTC\%20 Second $\% 20$ and $\% 2$ Final\%20Report $\% 20$ on $\% 20$ Estate\%20Duty.pdf

Du Preez, L., 2016, Interest-free loans to trusts under spotlight, viewed 8 June 2016, from http://www.iol.co.za/business/personal-finance/tax/interest-free-loans-totrusts-under-spotlight-1990570

Gordhan, P., 2013, Budget speech, viewed 16 July 2013, from http://www.treasury. gov.za/documents/national\%20budget/2013/speech/speech.pdf

Harbour and Associates, 2016, Trusts, estate planning and the 2016 budget speech, viewed 26 May 2016, from http://harbourassociates.co.za/blog/2015-07-18-1437-38/351-trusts-estate-planning-and-the-2016-budget-speech

Haupt, P., 2016, Notes on South African income tax, ABC Press, Roggebaai.

Hill, C., 2012, Seven reasons to consider setting up a trust, viewed 31 July 2013, from http://www.thesait.org.za/news/95883/.html

Holdstock, C.M., 2013, Trusts - Is the conduit principle in peril? viewed 17 July 2013, from http://www.mdacc.co.za/wp-content/uploads/2013/06/Trusts-is-theconduit-principle-in-peril.pdf

Hutchinson, T. \& Duncan, N., 2012, 'Defining and describing what we do: Doctrinal legal research', Deakin Law Review 17(1), 83-119. https://doi.org/10.21153/ dlr2012vol17no1art70

Mazansky, E., Killoran, R., Honiball, M. \& Rood, L., 2016, Trusts and estate duty, viewed 27 May 2016, from http://www.werksmans.com/legal-briefs-view/ 20162017-budget-proposals-tax-overview/

Ovenstone v SIR, 1980, 42 SATC 55, 2 All SA 25 (A)

Peacock, B., 2016, Trusts set to lose their allure as a tax haven, viewed 14 July 2013, from https://www.fisa.net.za/sunday-times-3-july-2016-trusts-set-lose-allure/

Rall-Willemse, S., 2016, 09 June, susanne@maraismuller.co.za

Republic of South Africa, 1955, Estate Duty Act No. 45 of 1955, Government Printer, Pretoria.

Republic of South Africa, 1962, Income Tax Act No. 58 of 1962, Government Printer, Pretoria.

SAIT, 2013, Reforming the taxation of trusts: A long time coming, viewed 26 May 2016 from http://www.thesait.org.za/news/118202/Reforming-the-taxation-of-trustsa-long-time-coming.htm

SARS, 2013, South African revenue service strategic plan, viewed 26 May 2016, from http://www.sars.gov.za/AllDocs/SARSEntDoclib/Ent/SARS-Strat-07\%20-\%20 SARS $\% 20$ Strategic $\% 2$ Plan $\% 202012 \% 202013 \% 20$ to $\% 202016 \% 202017$.pdf

Sebenza, 2013, Trust Q \& A, viewed 24 June 2013, from http://www.sebenzabiz.co.za/ trustsQA.htm

Stiglingh, M., Koekemoer, A.D., Van Schalkwyk, L., Wilcocks, J.S. \& De Swardt, R.D. 2016, SILKE: South African income tax 2016, LexisNexis, Durban.

Strydom, S., 2008, 'Good-bye interest-free loans?', Blue Chip Journal: Journal for Financial Planning and Management Wealth, viewed 27 May 2016, from http://www.bluechipjournal.co.za/index.php?option=com_content\&task=view\& $d=27 \& \mid$ temld $=30$ \&ed $=1$

Treasury, 2013, National budget review 2013 Chapter 4, viewed 26 May 2016, from http://www.treasury.gov.za/documents/national\%20budget/2013/review/ chapter\%204.pdf

Treasury, 2016a, National budget review 2016 Chapter 4, viewed 26 May 2016, from http://www.treasury.gov.za/documents/national\%20budget/2016/review/ chapter\%204.pdf

Treasury, 2016b, Tax pocket guide 2016, viewed 27 May 2016, from http://www. treasury.gov.za/documents/national\%20budget/2016/sars/Budget $\% 20$ PocketGuide\%202016-17.pdf

Treasury, 2016c, 2016 Draft Explanatory Memorandum on the Taxation Laws Amendment Bill, viewed 18 July 2016, from http://www.treasury.gov.za/ public $\% 20$ comments/TLAB\%20and $\% 20$ TALAB $\% 202016 \% 20$ Draft $/ 2016 \% 20$ Draft $\% 20$ Explanatory $\% 20$ Memorandum $\% 20$ on $\% 20$ the $\% 202016 \% 20$ Draft $\% 20$ Taxation\%20Laws\%20Amendment $\% 20$ Bill.pdf

Treasury, 2016d, 2016 Taxation Laws Amendment Bill, viewed 18 January 2017, from http://www.treasury.gov.za/legislation/bills/2016/Taxation\%20Laws $\% 20$ Amendment $\% 20$ Bill\%2017B\%20of\%202016.pdf

Warneke, D., 2016a, 'Uncertainty about tax proposals regarding trusts', Fin24, viewed 10 June 2016, from http://www.fin24.com/Money/Wills-and-trusts/uncertaintyabout-tax-proposals-regarding-trusts-20160308 